\title{
Shared mycorrhizae but distinct communities of other root- associated microbes on co-occurring native and invasive maples
}

\author{
Tonia DeBellis ${ }^{\text {Corresp., } 1,2}$, Steven W Kembel ${ }^{3}$, Jean-Philippe Lessard ${ }^{1}$ \\ 1 Department of Biology, Concordia University, Montreal, Quebec, Canada \\ 2 Department of Biology, Dawson College, Montreal, Quebec, Canada \\ 3 Département des sciences Biologiques, Université du Québec à Montréal, Montréal, Québec, Canada \\ Corresponding Author: Tonia DeBellis \\ Email address: tdebellis@dawsoncollege.qc.ca
}

Background. Biological invasions are major drivers of environmental change that can significantly alter ecosystem function and diversity. In plants, soil microbes play an important role in plant establishment and growth, however relatively little is known about the role they might play in biological invasions. A first step to assess whether root microbes may be playing a role in the invasion process is to find out if invasive plants host different microbes than neighbouring native plant species.

Methods. In this study we investigated differences in root associated microbes of native sugar maple (Acer saccharum Marsh.) and exotic Norway maple (A. platanoides L.) collected from a forested reserve in eastern Canada. We used microscopy to examine root fungi and high-throughput sequencing to characterize the bacterial, fungal and arbuscular mycorrhizal communities of both maple species over one growing season.

Results. We found differences in root associated bacterial and fungal communities between host species. Norway maple had a higher bacterial and fungal OTU (operational taxonomic units) richness compared to sugar maple, and the indicator species analysis revealed that nine fungal OTUs and three bacterial OTUs had a significant preference for sugar maple. The dominant bacterial phyla found on the roots of both maple species were Actinobacteria and Proteobacteria. The most common fungal orders associated with the Norway maple roots (in descending order) were Helotiales, Agaricales, Pleosporales, Hypocreales, Trechisporales while the Agaricales, Pleosporales, Helotiales, Capnodiales and Hypocreales were the dominant orders present in the Sugar maple roots. Dark septate fungi colonization levels were higher in the sugar maple, but no differences in arbuscular mycorrhizal fungal communities and colonization rates were detected between maple species.

Discussion: Our findings show that two congeneric plant species grown in close proximity can harbor distinct root microbial communities. These findings provide further support for the importance of plant species in structuring root associated microbe communities. The high colonization levels observed in Norway maple demonstrates its compatibility with arbuscular mycorrhizal fungi in the introduced range. Plant-associated microbial communities can affect host fitness and function in many ways; therefore, the observed differences suggest a possibility that biotic interactions can influence the dynamics between native and invasive species. 
1 Shared mycorrhizae but distinct communities of other root-associated microbes on co-

2 occurring native and invasive maples

3

4

5

6 Tonia De Bellis ${ }^{1,2}$, Steven W. Kembel ${ }^{3}$, Jean-Philippe Lessard ${ }^{1}$

7

$8 \quad{ }^{1}$ Department of Biology, Concordia University, Montreal, Quebec, Canada

$9 \quad{ }^{2}$ Department of Biology, Dawson College, Montreal, Quebec, Canada

10 32Département des sciences Biologiques, Université du Québec à Montréal, Montréal, Québec,

11 Canada

12

13 Corresponding Author:

14 Tonia De Bellis

153040 Sherbrooke Street West, Westmount, Quebec, H3Z 1A4, Canada

16 Email address: tdebellis@dawsoncollege.qc.ca

17

18

19

20

21

22 


\section{ABSTRACT}

25 Background. Biological invasions are major drivers of environmental change that can significantly alter ecosystem function and diversity. In plants, soil microbes play an important role in plant establishment and growth, however relatively little is known about the role they might play in biological invasions. A first step to assess whether root microbes may be playing a role in the invasion process is to find out if invasive plants host different microbes than neighbouring native plant species.

Methods. In this study we investigated differences in root associated microbes of native sugar maple (Acer saccharum Marsh.) and exotic Norway maple (A. platanoides L.) collected from a forested reserve in eastern Canada. We used microscopy to examine root fungi and highthroughput sequencing to characterize the bacterial, fungal and arbuscular mycorrhizal communities of both maple species over one growing season.

Results. We found differences in root associated bacterial and fungal communities between host species. Norway maple had a higher bacterial and fungal OTU (operational taxonomic units) richness compared to sugar maple, and the indicator species analysis revealed that nine fungal OTUs and three bacterial OTUs had a significant preference for sugar maple. The dominant bacterial phyla found on the roots of both maple species were Actinobacteria and Proteobacteria.

41 The most common fungal orders associated with the Norway maple roots (in descending order) 42 were Helotiales, Agaricales, Pleosporales, Hypocreales, Trechisporales while the Agaricales, 43 Pleosporales, Helotiales, Capnodiales and Hypocreales were the dominant orders present in the 44 Sugar maple roots. Dark septate fungi colonization levels were higher in the sugar maple, but no differences in arbuscular mycorrhizal fungal communities and colonization rates were detected

46 between maple species. 
47 Discussion: Our findings show that two congeneric plant species grown in close proximity can

48 harbor distinct root microbial communities. These findings provide further support for the

49 importance of plant species in structuring root associated microbe communities. The high

50 colonization levels observed in Norway maple demonstrates its compatibility with arbuscular

51 mycorrhizal fungi in the introduced range. Plant-associated microbial communities can affect

52 host fitness and function in many ways; therefore, the observed differences suggest a possibility

53 that biotic interactions can influence the dynamics between native and invasive species.

\section{INTRODUCTION}

56 Invasion of native ecosystems by non-native species can alter the structure of biological

57 communities, often leading to changes in biodiversity (Thomas \& Palmer, 2015; Bellard, Cassey

58 \& Blackburn, 2016) or ecosystem functioning (Ehrenfeld, 2010; Vilà et al., 2011). Studies

59 attempting to determine what factors may be playing a role in the invasion process have shown

60 that multiple factors such as facilitation, enemy release, competitive release and propagule

61 pressure can simultaneously influence invasion success (Lockwood, Hoopes \& Marchetti, 2006).

62 Invasions of trees and shrubs in the last few decades around the world has revealed that woody

63 plants are among the most widespread of invasive organisms (Richardson \& Rejmánek, 2011).

64 Natural plant populations associate with a multitude of soil microbes and several hypotheses

65 aimed at explaining the success of exotic plants revolve around the biotic interactions between

66 plants and their associated microbial communities. Feedback between plants and root-associated

67 microbes can be positive when mycorrhizal fungi and $\mathrm{N}$-fixing bacteria are involved, or negative

68 when the plant associates with microbial pathogens and parasites (Bever, 2003). Therefore,

69 microbial communities in soil can influence invasion success of plants in several ways (Wolfe \& 
70 Klironomos, 2005; Reinhart \& Callaway, 2006; Pringle et al., 2009). Nevertheless, how soil

71 microbial communities differ between native and exotic plant species remains largely

72 unexplored. Here, we investigate differences in the microbes associated with the roots of native

73 sugar maple and exotic Norway maple from a forested reserve in eastern Canada.

74 Several mechanisms directly or indirectly involving soil microorganisms are proposed to explain the success of invasive plants in their introduced ranges. The two functional groups of microbes hypothesized to have strong effects on invasive plants are the pathogens and mutualistic symbionts due to their important influence on plant growth and performance.

Pathogens that are present in the native range may not occur in the introduced range such that exotic species gain a competitive advantage over native species (Callaway et al., 2004; Reinhart et al., 2010). This phenomenon is consistent with the enemy release hypothesis, which posits that invasive species thrive in their new range by no longer being hindered by their natural enemies (Elton, 1958; Keane \& Crawley, 2002). For plants that require soil-borne mutualists, various strategies facilitating invasion have been proposed. Plants will not be hindered in their new range if they are able to associate with novel mutualists, associate with generalist symbionts, or co-invade with their native symbionts (Nuñez \& Dickie, 2014). Although the role of soil microbes in the invasion process of plants is becoming increasingly recognized (Wolfe \&

87 Klironomos, 2005; Reinhart \& Callaway, 2006; Inderjit \& van der Putten, 2010; Dickie et al., 88 2017), we still lack an understanding of these complex dynamics for most introduced species. Plants and soil microbes form complex interactions which can affect host fitness and

90 function (Vandenkoornhuyse et al., 2015). Many bacteria are known to be able to stimulate plant 91 growth through direct or indirect interactions with plant roots. Root associated bacteria may 92 contribute to plant nutrition by nutrient solubilization or nitrogen fixation; to plant growth and 
93 stress release by phytohormone production or degradation, and to pathogen suppression (Berg et

94 al., 2016). Soil fungi also assist plants with nutrient availability, protection against pathogens and

95 stress tolerance (Rodriguez \& Redman, 2008; Van Wees, Van der Ent \& Pieterse, 2008;

96 Vandenkoornhuyse et al., 2015). Soil bacteria and fungi can also be pathogenic to plants and can

97 therefore affect the distribution and abundance of plant species by suppressing plant recruitment,

98 growth and survival (Packer \& Clay, 2000; Bever, 2003; Reinhart et al., 2003). An

99 understanding of these complex relationships requires an assessment of the resident microbes on

100 different plant hosts.

101 Plant species identity can be an important factor influencing root microbial diversity;

102 however, this relationship is not universal. It has been shown to be a significant factor in some

103 field studies (Aleklett et al., 2015; Uroz et al., 2016) and not significant in others (Knapp, Pintye

104 \& Kovács, 2012; Johansen et al., 2016). The phylogenetic relationship among plant hosts being

105 compared may be an important factor affecting plant-microbe associations. Related plants tend to

106 have more similar microbial communities because host traits that influence interactions with

107 microbes tend to be phylogenetically conserved (Wehner et al., 2014). Laforest-Lapointe et al.

108 (2016) examined bacterial communities of five temperate tree species and found that red maple

109 (A. rubrum L.) and sugar maple have similar bacterial communities when compared to paper

110 birch (Betula papyrifera Marsh.) and to the two coniferous species sampled. However, other

111 studies have reported the opposite, with closely related plant species hosting distinct root

112 microbes (Reinhart \& Anacker, 2014; Veresoglou \& Rillig, 2014). Hence, a first step to infer the

113 role of soil microbes in the invasion process is to discover if there are different communities of

114 microbes around two congeneric plant species growing in close vicinity. 
115 Norway maple is an invasive tree species found in temperate forests of the northeastern

116 United States and Canada. It is a European native that was introduced to North America around

1171756 (Nowak \& Rowntree, 1990). It became a popular choice for street trees after WWII when

118 the native white elm population (Ulmus americanum L.) was devastated by Dutch Elm disease

119 (Nowak \& Rowntree, 1990), but it is now invading wild woodland and natural areas in urban

120 settings. Previous studies attributed the success of the Norway maple in its introduced range to

121 its fast growth, high shade tolerance, high seed output, and tolerance to a wide range of

122 environmental conditions (Kloeppel \& Abrams, 1995; Wyckoff \& Webb, 1996; Webb et al.,

123 2000; Meiners, 2005). Many studies have reported reduced species richness of native species and

124 increased abundances of Norway maple seedlings relative to nearby non-invaded areas (Wyckoff

125 \& Webb, 1996; Martin, 1999; Reinhart, Greene \& Callaway, 2005). Norway maple can inhibit

126 the growth of native species (Reinhart, Greene \& Callaway, 2005; Galbraith-Kent \& Handel,

127 2008) including the native sugar maple by outcompeting it (Wyckoff \& Webb, 1996; Martin,

128 1999). Reinhart \& Callaway (2004) have shown that Norway maple can experience increased

129 growth when grown in soil from its invaded range, and another experimental study showed that

130 Norway maple had significantly greater aboveground and root biomass than sugar maple

131 (Paquette et al., 2012). However, no study to date has investigated whether there are differences

132 in root microbial communities associated with native and introduced maples using amplicon

133 sequencing of DNA extracted directly from root tissue.

134 The roots of maple trees (Acer spp.) are colonized by arbuscular mycorrhizal fungi

135 (hereafter AMF), which are symbiotic micro-organisms that colonize the roots of the majority of

136 the world's land plant species (Smith \& Read, 2008). AMF provide host plants with nutrients,

137 water, heavy metal tolerance, and/or enhanced pathogen resistance in exchange for carbon 
138 (Smith \& Read, 2008) and could therefore promote the establishment and spread of invasive

139 plant species (Marler et al., 1999). A meta-analysis of 67 studies found that the degree of AMF

140 colonization (measured as a percentage) of invasive plants did not differ from that of native

141 species across studies, but AMF communities associated with co-occurring invasive and native

142 plants can differ substantially (Bunn, Ramsey \& Lekberg, 2015). Different AMF fungi have

143 differing effects on their host (Klironomos, 2003), therefore changes in AMF communities may

144 impact plant performance and competitiveness. Studies show that exotic plants are primarily

145 colonized with dominant, widespread AMF rather than rare AMF taxa (Moora et al., 2011; Bunn

146 et al., 2014). Most AMF have low levels of endemism (Davison et al., 2015), therefore these

147 widespread AMF with low species specificity may have the ability to quickly colonize alien

148 hosts, possibly aiding the invasion process (Moora et al., 2011; Dickie et al., 2017). Beyond

149 overall root colonization levels, another method used to further examine the state of the AMF

150 symbiosis is to examine the arbuscule to vesicle ratio. Arbuscules are the site of nutrient

151 exchange in AMF, while vesicles are fungal storage structures (Smith \& Read, 2008), therefore,

152 high arbuscule numbers coupled with low vesicle numbers is usually a sign of a healthy

153 mycorrhizal association. A decreased number of arbuscules with higher vesicle numbers have

154 been observed in the roots of stressed sugar maples (Cooke, Widden \& Halloran, 1992;

155 Klironomos, 1995). A higher arbuscule to vesicle ratio can reveal another competitive advantage 156 in co-occurring plant species.

157 Here, we examined the microbial communities associated with the roots of co-occurring 158 non-native Norway maple and native sugar maple from a temperate forested reserve. We used

159 microscopy and DNA sequencing-based methods targeting bacteria, fungi and AMF in maple

160 roots to address the following questions: 1) do root-associated microbial communities vary in 
161 their composition between co-occurring native and exotic maple seedlings? 2) do root fungal

162 colonization rates differ between the two species? 3) are the arbuscule to vesicle ratios higher in

163 the Norway maple?

164

165 MATERIALS \& METHODS

166 Study site and root collection

167 Maple seedlings were collected from the Morgan Arboretum, a forested reserve located in

168 Sainte-Anne-de-Bellevue, Québec, Canada $\left(45^{\circ} \mathrm{N}, 25^{\circ} \mathrm{W}\right)$. Norway maple trees were planted in

169 the Arboretum in the mid-1950s, and these mature trees were cut and removed from the site in

170 2008. Although mature trees have been removed, many seedlings are still present in the reserve.

171 In an area containing many Norway and sugar maple seedlings, five parallel $60 \mathrm{~m}$ transects

172 (separated by 10m) were set up. Along each transect, we randomly selected a sampling point. On

173 each sampling date, one Norway maple and one sugar maple seedling of similar height $(\sim 25 \mathrm{~cm})$

174 were sampled within a radius of $1.5 \mathrm{~m}$ for each transect. A total of 10 seedlings were collected on

175 each sampling date. Seedlings were selected because entire seedlings could be collected in the

176 field ensuring the exact identification of each root system examined. We repeated this protocol 8

177 times at intervals of two weeks between June and October 2015. A total of 80 seedlings were

178 collected ( 5 transects $\times 8$ dates $\times 2$ species). Each seedling was removed from the soil with a

179 trowel, leaving soil around the roots to prevent desiccation. Seedlings were then placed in

180 sealable plastic bags and stored in a cooler with ice packs until they were returned to the

181 laboratory for further processing.

182 Once in the laboratory, roots were carefully removed from the soil, were thoroughly

183 washed with tap water and the small pale feeder roots were isolated. Half of the roots were 
184 preserved in Formalin-Acetic Acid-Alcohol (FAA) solution at room temperature for a minimum

185 of 24 hours for the morphological analysis and the other half were dried using paper towels and

186 placed in $1.5 \mathrm{ml}$ microtubes and stored at $-80^{\circ} \mathrm{C}$ for the molecular analysis of the root microbial

187 community. While collecting the roots, approximately $100 \mathrm{ml}$ of soil surrounding the roots of

188 each seedling was collected, air-dried for $48 \mathrm{hrs}$ and stored in paper bags for soil chemical

189 analysis (see supplementary materials for details of the soil chemical analyses). Seedling

190 collection and root processing until this point occurred on the same day.

191

192 DNA Extraction

193 DNA was extracted from approximately $150 \mathrm{mg}$ of root sample using the PowerSoil DNA

194 Isolation Kit (MOBIO Laboratories, Inc., CA, USA) with the two following modifications.

195 Firstly, in order to increase cell disruption and increase DNA yield, samples were milled using a

196 MiniBead Beadbeater-16 (BioSpec Products, Bartlesville, OK, USA) for 2 minutes with three

197 2.3mm diameter stainless steel beads (BioSpec Products). After this step, the roots were paste-

198 like in consistency therefore the contents of the PowerBead Tubes tube were added to the tubes

199 containing the crushed roots and the procedure was continued following manufacturer's

200 instructions. The second modification occurred at the final elution step, where $75 \mu \mathrm{l}$ of solution

201 C6 solution was added to the spin filter tube instead of the recommended $100 \mu$, also an effort to 202 increase final DNA concentration. Extracted DNA was stored at $-80^{\circ} \mathrm{C}$.

203

204

DNA library preparation and sequencing

205 For bacteria, we amplified the V5-V6 region of the bacterial 16S ribosomal RNA gene using the 206 chloroplast-excluding primers 799F-1115R (799F: AACMGGATTAGATACCCKG; 1115R: 
207 AGGGTTGCGCTCGTTG; Chelius \& Triplett, 2001; Redford et al., 2010) in order to eliminate

208 contamination by host plant DNA. For the fungal communities, the internal transcribed spacer

209 (ITS) region was amplified using the fungal specific primers ITS-1F

210 (CTTGGTCATTTAGAGGAAGTAA; Gardes \& Bruns, 1993) and ITS2

211 (GCTGCGTTCTTCATCGATGC; White et al., 1990). For the AMF, we used the

212 Glomeromycota specific primer AML2 (GAACCCAAACACTTTGGTTTCC; Lee \& Young, 213 2008) and the universal eukaryotic primer WANDA (CAGCCGCGGTAATTCCAGCT;

214 Dumbrell et al., 2011). The WANDA and AML2 primer pair amplifies a portion of the small

215 subunit (SSU) RNA gene. We chose this region because it is frequently targeted, and the curated

216 MaarjAM database (Öpik et al., 2010) has been developed based on this region, allowing us to

217 compare our sequences to the largest AMF sequence database to date.

218 The forward and reverse primers used in the PCR consisted of the target primer, a unique

219 twelve-nucleotide barcode, and an Illumina adaptor (5' - Illumina adaptor - 12 nucleotide

220 barcode - target primer). Reactions were performed using 0.5 unit of Phusion Hot Start II High-

221 Fidelity DNA polymerase and accompanying 5X Phusion HF Buffer (ThermoScientific) with

$2221 \mu \mathrm{L}$ of undiluted root DNA for bacteria and fungi but a 1/10 DNA dilution was used for the

223 AMF. The reactions were carried out in a final volume of $25 \mu \mathrm{l}$ in the presence of $200 \mu \mathrm{M}$

224 dNTPs, 200 pmols of each primer, and $0.75 \mu \mathrm{l}$ of DMSO. The reaction was run on an Eppendorf

225 MasterCycler thermocycler with a $30 \mathrm{~s}$ initial denaturation step at $98^{\circ} \mathrm{C}$ and 35 cycles of $98^{\circ} \mathrm{C}$

226 for $15 \mathrm{~s}$, annealing at $64^{\circ} \mathrm{C}$ for $30 \mathrm{~s}$, and extension at $72^{\circ} \mathrm{C}$ for $30 \mathrm{~s}$, with a final extension at

$22772^{\circ} \mathrm{C}$ for $10 \mathrm{~min}$. Controls with no DNA and positives with target DNA were run with every

228 series of amplifications to test for the presence of contaminants and ensure PCR reaction mix

229 was correct. The resulting PCR products were loaded on a 1\% agarose gel to verify each PCR 
230 run. All amplified samples were cleaned and normalized using the Invitrogen Sequalprep PCR

231 Cleanup and Normalization Kit. Multiplexed amplicon libraries for each of the 3 groups were

232 prepared by mixing equimolar concentrations of DNA, and each library was quantified using

233 Qubit dsDNA High Sensitivity kit. Each DNA library was sequenced using an Illumina MiSeq

234 Sequencer with the $2 \times 300$ bp paired end platform using the Illunima MiSeq Reagent Kit v3.

Bioinformatics

237 Illumina adapters were trimmed from the raw sequences using BBDuk (BBtools package,

$238 \mathrm{https://jgi.doe.gov/data-and-tools/bbtools/),} \mathrm{and} \mathrm{the} \mathrm{trimmed} \mathrm{paired-end} \mathrm{sequences} \mathrm{were}$

239 assembled with PEAR (Zhang et al., 2014). Sequences were demultiplexed using default settings

240 in QIIME (v. 1.9.1) (Caporaso et al., 2010) with the exception of allowing for 2 primer

241 mismatches. Chimeric sequences were identified using the Usearch algorithm and then

242 eliminated. We then binned the remaining sequences into operational taxonomic units (OTUs) at

243 a $97 \%$ sequence similarity cutoff. Taxonomic identity of each OTU was determined with QIIME

244 using the uclust algorithm and the Greengenes database ver 13_8 (DeSantis et al., 2006) for

245 bacteria; RDP classifier and the UNITE database ver 12_11 (Koljalg et al., 2005) for fungi, and

246 the uclust algorithm and MaarjAM database for AMF (Öpik et al., 2010).

Root staining and quantification of AMF and Dark Septate Endophyte colonization in maple

249 roots

250 The preserved roots were removed from the FAA solution and placed separately in OmniSette ${ }^{\circledR}$

251 Tissue-Teks ${ }^{\circledR}$ (Fisher Scientific). Samples were then cleared by autoclaving for 20 minutes in

$25210 \% \mathrm{KOH}$. The autoclave step was repeated two times, changing the $\mathrm{KOH}$ solution each time. If 
253 the $\mathrm{KOH}$ solution was a dark brown color after the second autoclave step the process was

254 repeated a third time in order to ensure the roots would be sufficiently cleared for morphological

255 analysis. Following the $\mathrm{KOH}$ step, roots were gently rinsed with tap water and bleached with

$25635 \%$ hydrogen peroxide for 30 minutes. Samples were then rinsed again with tap water and

257 acidified in $15 \% \mathrm{HCl}$ for 15 minutes. Finally, roots were stained in $0.1 \%$ chlorazol black $\mathrm{E}$ at

$25890^{\circ} \mathrm{C}$ for 12 minutes (Brundrett, Piché \& Peterson, 1984). After staining, the samples were

259 allowed to destain in a 50\% glycerin solution overnight. The roots were then mounted on slides

260 in glycerine jelly and squashed with a cover slip (Widden, 2001). Root fungi were examined

261 using a Leica DM6000 light microscope at a magnification of 400x. The colonization rate for

262 each root sample was quantified using the magnified grid-intersect method (McGonigle et al.,

263 1990). Each intersect was evaluated for the following AMF structures: hyphae, arbuscules and

264 vesicles, for a total of 100 intersects per root sample. For each fungal structure, the colonization

265 rate was determined by counting the total number of intersects in which it was present. Total

266 AMF colonization rates were determined by counting all intersects in which at least one AMF

267 structure was present. When the stained roots were observed under the microscope, the dark

268 septate endophytic (DSE) fungi were clearly evident and easily distinguishable from the AMF,

269 therefore at each intersect the presence of these fungi were also noted and quantified.

271 Statistical analysis

272 Prior to the analyses of the microbial sequence data, in order to eliminate potentially spurious

273 OTUs caused by PCR error or sequencing artifacts, all OTUs with fewer than 10 occurrences

274 were removed and the number of sequences per microbial community was rarefied based on the

275 number of sequences present in the sample with the lowest number sequences in order to 
276 maintain equal sampling depth across samples. To illustrate differences in the structure of

277 bacterial and fungal communities, non-metric multidimensional scaling (NMDS) analysis based

278 on Bray-Curtis similarities at the OTU level (using Hellinger transformation) was used, and the

279 significance of the observed differences were determined by PERMANOVA (distance-based

280 permutational multivariable analysis of variance, Anderson 2001) using 999 permutations. To

281 identify which OTUs differed in abundance between maple species we used ANCOM (Analysis

282 of composition of microbiomes; Mandal et al. 2015) implemented in R, with the multcorr2

283 parameter. ANCOM was used because of its power and accuracy in the detection of differential

284 abundance of OTUs and for its low false detection rate (Weiss et al., 2017). For this analysis,

285 unrarefied community datasets are used, and all OTUs with fewer than 10 sequence reads were

286 removed. We also classified the functional guild of the 25 most common fungal OTUs using

287 FUNGuild (Nguyen et al., 2016). These 25 OTUs included all OTUs that had $>0.5 \%$ relative

288 abundance for each maple species. In brief, FUNGuild uses the given OTU taxonomy assigned

289 file to compare it to its database to attempt to assign an ecological guild to each OTU. For each

290 match a confidence rating is also given with highly probable being absolutely certain, probable

291 being fairly certain and the lowest rating being possible, meaning the identification is suspected

292 but not highly supported.

293 We calculated richness of all three microbe groups from the OTU community matrices

294 and performed t-tests to test for differences between species. The overall effects of species, date

295 and interaction between species and date on AMF and DSE colonization were determined with

296 two-way ANOVAs. Two-way ANOVAs were also used to determine if there were any

297 significant differences in soil chemical parameters with species and sampling date. When data

298 did not satisfy the Shapiro-Wilk test for normality a log transformation was performed. All 
299 statistical analyses and visualization were performed in R (R Development Core Team, 2013)

300 using the following packages: ggplot2 (Wickham, 2009), picante (Kembel et al., 2010), vegan

301 (Oksanen et al., 2017), and ANCOM (Mandal et al., 2015).

302 The metadata and sequences files have been deposited in Figshare.

303

304 RESULTS

305 Taxonomic identification of soil microbial communities associated with the roots of Norway and

306 sugar maples

307 Due to a contamination with one of the forward primers used, all 10 samples from the June

308 sampling date were removed from the analysis and we did not obtain any sequences from one

309 Norway maple sampled on July $11^{\text {th }}$. From the remaining 69 samples, we obtained a total of

310207280 bacterial sequences after quality trimming and the removal of chimeras. Once all OTUs

311 with fewer than 10 sequences were removed, and the dataset was rarefied to 1000 sequences per

312 sample, a total of 66 samples and 1077 OTUs remained and were used in the analyses. A total of

31318 bacterial phyla were detected from the maple roots, and these 18 phyla were further classified

314 into 47 bacterial orders with 12 having an abundance of over 1\% (Fig. 1a). Approximately 16\%

315 of the OTUs were not identified to order.

316 A total 256389 fungal (ITS) sequences were obtained after quality trimming and the

317 removal of chimeras. When all OTUs with fewer than 10 sequences were removed, and the

318 dataset was rarefied to 1000 sequences per sample, a total of 75 samples were included in the

319 analyses and the remaining sequences clustered into 474 OTUs. The majority of OTUs were

320 Basidiomycota (50.2\%), followed by Ascomycota 31.1\%, Glomeromycota 4.3\%, Zygomycota

$321 \quad 1.7 \%$ and $12.7 \%$ were unidentified at phylum level. The OTUs were classified into 40 orders, 
322 with 11 having a relative abundance of over 1\% (Fig. 1b).

323 Using the AMF specific primers, we obtained sequences from 79 of the 80 samples. A

324 total of 166403 sequences were obtained after quality trimming and the removal of chimeras.

325 Once all OTUs with fewer than 10 sequences were removed, and the dataset was rarefied 800, a

326 total of 76 samples were included in the analyses and the remaining sequences clustered into 199

327 OTUs. The relative abundance of the AMF OTUs classified to family level was similar for both

328 host species (Fig. 1c).

330 Quantification of differences in the composition of soil microbial communities associated with

331 the roots of Norway and sugar maples

332 We found that the composition of bacterial and fungal communities associated with the roots of

333 Norway and sugar maple were distinct from each other, while the AMF communities were not

334 distinguishable based on plant host (Fig.2, Table 1). Host species explained 3.6\% of the variation

335 in root bacterial and $8.4 \%$ of the variation for the fungal community structure. Sampling date

336 explained $3.6 \%$ of the total variation in the bacterial communities and had no significant effect

337 on the variation in the fungal communities (Table 1).

338 We also found significant differences in the relative abundance of particular OTUs

339 between the native and invasive species. Many OTUs from each microbial group were found in

340 both maple species, with plant hosts sharing $95.4 \%, 65.6 \%$ and $83 \%$ of all bacterial, fungal and

341 AMF OTUs, respectively. However, when we compared OTU abundance between species using

342 ANCOM (Mandal et al. 2015), we found 3 bacterial and 10 fungal (ITS) OTUs whose

343 abundances differed significantly between the sugar and Norway maples $(\mathrm{P}<0.05$, Fig. 3$)$. All 3

344 bacterial OTUs and 9 of the 10 fungal OTUs had significantly higher abundance in sugar maple 
345 compared to Norway maple (Fig. 3). The ten fungal OTUs that varied significantly in abundance

346 between maple species, represent $12.1 \%$ of the relative sequence abundance in Norway maple

347 and $39.7 \%$ of the sequences in sugar maple. The nine fungal OTUs that were found in

348 significantly greater abundances in sugar maple accounted for $37 \%$ of its total OTU relative

349 abundance compared to only $6.6 \%$ in Norway maple. The three differentially abundant bacterial

350 OTUs represent $7.2 \%$ and $15.0 \%$ of the relative sequences in Norway maple and sugar maple, 351 respectively.

352 Only 8 out of the 25 most commonly occurring OTUs could be classified to a functional 353 group using FUNGuild, with the remaining left unidentified. These 25 OTUs made up $74 \%$ of

354 the relative OTU abundance in Norway maple and $82 \%$ in sugar maple. Only two OTU

355 functional guild classifications were ranked as highly probable and both were categorized as 356 symbiotic ectomycorrhizal fungi. Four OTUs were ranked as probable and two possible. These

357 six OTUs were either classified as solely saprotrophs or another category which included 358 saprotrophs, symbionts and pathogens. The top two fungal OTUs with higher abundances in 359 sugar maple (Fig 3, Didymosphaeriaceae and Entoloma sp), were classified as saprotroph-

360 symbiont-pathogen with Didymosphaeriaceae having the 'probable' rating and Entoloma sp.

361 'possible'. These two OTUs made up 30.8\% and 5.2\% of the OTU relative abundance in sugar 362 and Norway maple, respectively.

363

364 Quantification of differences in the richness of soil microbial communities on the roots of

365 Norway and sugar maples

366 Bacterial OTU richness was significantly higher in Norway maple (288.23 \pm SE 4.87) compared

367 to sugar maple $(251.74 \pm \mathrm{SE} 5.29, t$-test; $\mathrm{P}<0.001)$. The same pattern was seen with the fungi, 
368 with Norway maple having an OTU richness of $54.72 \pm$ SE 2.76, and sugar maple $45.97 \pm$ SE

$3692.36(t$-test; $\mathrm{P}=0.02)$. AMF OTU richness did not differ between species. Norway maple had an

370 OTU richness of 28.87 \pm SE 1.58 and sugar maple AMF OTU richness was $27.94 \pm$ SE $2.08(t$ -

371 test; $\mathrm{P}=0.72)$.

372

373 Quantification of differences in colonization rates of AMF and DSE on the roots of Norway and

374 sugar maples

375 Overall, there was no significant effect of maple species on total AMF colonization (ANOVA;

$376 \mathrm{~F}_{1,64}=0.24, \mathrm{P}=0.62$ ). Total AMF colonization rates were equally high in both Norway maple

377 and sugar maples with an average of $81.1 \%$ and $80 \%$, respectively. However, date $\left(\mathrm{F}_{7,64}=22.09\right.$,

$378 \mathrm{P}<0.001)$ and the interaction between species and date $\left(\mathrm{F}_{7,64}=2.94, \mathrm{P}=0.01\right)$ was significant.

379 There was no significant effect of maple species on the abundance of arbuscules

$380 \quad\left(\right.$ ANOVA; $\left.F_{1,64}=0.206, P=0.651\right)$ and vesicles $\left(F_{1,64}=0.029, \mathrm{P}=0.865\right)$. The abundance of

381 vesicles was low with an average of 2 and $2.1 \%$, for the Norway and sugar maples respectively

382 (Fig. 4a), while the abundance of arbuscules was similar and quite high in the Norway and sugar

383 maples with an average abundance of $77.9 \%$ and $76.6 \%$ respectively (Fig. $4 \mathrm{~b}$ ). However, the

384 effect of date on the abundance of arbuscules and vesicles was significant $\left(\mathrm{F}_{7,64}=29.96, \mathrm{P}=\right.$

3850.006 and $F_{7,64}=9.16, P<0.001$, respectively). There was also a significant interaction effect

386 between maple species and date on the abundance of arbuscules $\left(\mathrm{F}_{7,64}=3.152, \mathrm{P}=0.006\right)$ but not

387 for vesicle abundance $\left(\mathrm{F}_{7,79}=1.28, \mathrm{P}=0.274\right)$. No differences in vesicle and arbuscule

388 colonization levels were detected between maples species at any of the eight sampling dates

389 (Tukey post-hoc test, $\mathrm{P}>0.05$ ).

390 There was a significant effect of maple species and date on the colonization of dark 
391 septate endophytes (ANOVA; species: $\mathrm{F}_{1,64}=25.56, \mathrm{P}<0.001$; date: $\mathrm{F}_{7,64}=5.86, \mathrm{P}<0.001$ ), but

392 the interaction term was not significant $\left(\mathrm{F}_{7,64}=2.10, \mathrm{P}=0.06\right)$. The average rate of colonization

393 of dark septate endophytes in the Norway maple and sugar maple was $16.5 \%$ and $33.4 \%$,

394 respectively (Fig. 4c). DSE were significantly more abundant in the sugar maple compared to

395 Norway maple on August 28 and September 13 (Tukey post-hoc test, $\mathrm{P}<0.05$, Fig 4c).

396

397 Chemical analysis of the soil surrounding the Norway and Sugar maple roots

398 There were no significant differences in any of the measured soil chemical parameters among

399 species and sampling dates (ANOVA tests; all P > 0.05). The only significant effect observed

400 was the interaction term of species and date with $\mathrm{C} / \mathrm{N}$ ratio $(\mathrm{P}=0.04) . \mathrm{C} / \mathrm{N}$ ratio decreased with

401 time for Norway maple but slightly increased for sugar maple. ANOVA results and chemical

402 analyses of the soil data set can be found in supplementary materials.

403

404 DISCUSSION

405 We examined the community composition of different groups of microbes simultaneously from

406 the roots of Norway maple and sugar maple, and we show that soil microbial communities

407 associate differently with host species. Our findings are consistent with the body of evidence

408 showing that plant species identity can influence soil bacterial and fungal communities (Haichar

409 et al., 2008; Berg \& Smalla, 2009; Leff et al., 2018; Linde et al., 2018). We observed small but

410 significant differences in microbial communities between these two co-occurring maple species

411 albeit other work has suggested that closely related plants tend to share microbial communities

412 (Gilbert \& Webb, 2007; Wehner et al., 2014; Johansen et al., 2016), and time since invasion can

413 diminish the impact of an invasive plant on the communities of soil microbes (Lankau, 2011). 
Although host species has been shown to be an important factor shaping root associated

415 microbes, numerous other factors also influence their community composition. The most

416 abundant bacterial phyla in the maple roots were Proteobacteria and Actinobacteria. This is in

417 agreement with a study by Wallace et al. (2018) who examined microbes from roots and leaves

418 of sugar maple seedings collected from a national park in eastern Quebec using similar methods.

419 Proteobacteria and Actinobacteria were the most prevalent bacterial root endophytes in their

420 samples, with Actinobacteria being an indicator taxon for the root compartment. However, there

421 are distinct differences in the distribution of the dominant fungal taxa between our study and

422 Wallace et al (2018). The main fungal taxa we observed in the sugar maples were Ascomycota

$423(52.7 \%)$ and Basidiomycota (41.7\%), while the dominant fungal taxon reported by Wallace et al

424 (2018) is Zygomycota (46.4\%), followed by Ascomycota (40.1\%), and they report relatively

425 little Basidiomycota (12.4\%). Some of the variation observed between the two studies may be

426 attributed to time of sampling and site. Wallace et al (2018) only sampled once in the month of

427 July and we sampled every two weeks from June to October for a total of 8 sampling periods.

428 The multiple sampling periods may give a better overall representation of the fungi on the maple

429 roots. However, date was not a significant factor explaining the variation of the fungal

430 communities in our study (Table 1). Site differences may also be an important factor explaining

431 for variation in fungal communities. An obvious site difference between our study and that of

432 Wallace et al (2018) is that we sampled at a site where Norway maple has been present for over

43350 years, with a high recruitment of Norway maple seedlings, therefore the soil microbes at our

434 sampling location may be conditioned by its presence. The microbial assessment of maples at

435 several locations would have to be compared in order to assess how much of the variation in 
436 fungal communities in sugar maples is a result of the presence of neighbouring Norway maples

437 and other inter-site variations.

438 We detected higher bacterial and fungal richness on Norway maple compared to sugar

439 maple, which may benefit the invasion process. Legumes that are able to associate with more

440 bacterial species can successfully establish into new ranges compared to legumes that associate

441 with a lower diversity of taxa (Harrison et al., 2018). Toole et al. (2017) found higher fungal

442 OTU richness in rhizosphere soils of Norway maple compared to sugar maple, however, they

443 correlated fungal richness to plant weediness and not solely by the plant's invasive status. In

444 their study, both the native and weedy red maple and invasive, weedy Norway maple had a

445 higher fungal richness than native, non-weedy sugar maple and Japanese Maple (A. palmatum

446 Thunb.), an introduced non-weedy plant, hence non-invasive species. More field sites and plant

447 species would need to be sampled in order to determine if increased richness in root associated

448 microbial communities is a common trend for range expanding species.

449 We observed high AMF colonization rates, in the roots of Norway maple, demonstrating

450 its ability to effectively tap into the established native AMF network. We did not observe any

451 differences in AMF community structure, colonization rates, or arbuscule to vesicle ratio

452 between host species. This was somewhat contrary to what we predicted, but it does indicate that

453 Norway maple is not hindered by a lack of suitable AMF in the introduced range. Moreover, it is

454 possible that Norway maple derives more benefit from these associations with native AMF than

455 does the sugar maple. Klironomos (2003) has shown that AMF can have different impacts on

456 different plant species. An AMF survey by Öpik et al. (2009) showed that AMF specificity is

457 more likely to occur at the level of ecological group rather than at the species level. The

458 similarities in AMF communities between host species may be explained by the fact that we two 
459 maple species collected from a single location, observed no significant difference in soil

460 chemistry surrounding the maple roots, and plants grown in close proximity can share

461 mycorrhizal networks (van der Heijden \& Horton, 2009). Our results agree with other analyses

462 of AMF in natural communities that have revealed that widely distributed AMF tend to associate

463 with widely distributed habitat generalist plants (Öpik et al., 2009), and associating with

464 generalist symbionts is proposed as a strategy for invasive plant species to avoid mutualism

465 limitation in its novel range (Moora et al., 2011; Nuñez \& Dickie, 2014).

466 Using morphological assessment of the root fungi, we found higher abundance of dark

467 septate endophytes (DSE) on sugar maple compared to Norway maple. DSE are a group of

468 ubiquitous ascomycete fungal root colonizers grouped together based on morphological

469 characteristics (Jumpponen \& Trappe, 1998; Newsham, 2011; Mandyam \& Jumpponen, 2015).

470 Despite the global distribution of DSE, their ecological role is still not well understood and

471 ranges from beneficial to pathogenic (Jumpponen, 2001). DSE are not a taxon, therefore this

472 range of ecological roles most likely results from the various taxa belonging to several orders of

473 the phylum Ascomycota that are included in this group (Jumpponen \& Trappe, 1998; Newsham,

474 2011; Porras-Alfaro et al., 2014). Of the nine fungal OTUs that had significantly higher

475 abundances in sugar maple, four belong to the order Pleosporales, an order belonging to the DSE

476 group (Jumpponen and Trappe 1998). Although the ecological function of DSE is not well

477 understood and historically they have predominately been considered benign, studies have

478 reported negative effects of root DSE in tree species (Wilcox \& Wang, 1987; Tellenbach, Grünig

479 \& Sieber, 2011; Mayerhofer, Kernaghan \& Harper, 2013). Furthermore, Tellenbach et al. (2011)

480 not only showed that DSE had pathogenic effects but also showed that virulence was positively

481 correlated with the extent of fungal colonization. Therefore, if DSE do negatively impact maple 
482 species, we observed lower levels of DSE in Norway Maple roots compared to sugar maple,

483 providing support for a possible reduced soil enemy effect in the invasive maple. We did observe

484 that certain fungal OTUs were more abundant on the roots of sugar maple relative to Norway

485 maple, unfortunately the FUNGuild results did not provide strong evidence for the pathogenicity

486 of these fungi. Whether DSE do have negative effects on the maple species will need to be

487 verified experimentally since we could not quantify the functional role of DSE in this particular 488 study system.

489

490 CONCLUSIONS

491 Here, we quantified the community composition of three microbial groups on the roots of

492 Norway maple and sugar maple and showed that the bacterial and fungal communities varied

493 between the two species, but no differences were found with AMF. Consequently, in order to

494 obtain a full picture of the differences in root associated microbes between host species an

495 assessment of the various microbial taxa is required. Specific microbes can have different

496 impacts on different plant host and specific plant-microbe associations can affect plant

497 coexistence (Bever 2003); therefore, our observed patterns suggest a potential for belowground

498 biotic interactions playing a role in Norway maple's invasion in North American temperate

499 forests. Future work will be required to assess the functional capabilities of these microbes to

500 determine their roles on the different maple species. The fact that we did observe differences in

501 root microbes between the two species highlights the need to consider diverse microbial taxa

502 when assessing the role of plant-soil interactions in the context of plant invasions.

503

504 ACKNOWLEDGEMENTS 
505 We gratefully acknowledge Victoria Pompa for her field assistance and for the morphological

506 analysis of the roots. We also thank Evan Wisdom-Dawson, Richard Calvé, Alana Di Vito, Sean

507 Di Paolo, who helped with the seedling collection and/or root washing, and Geneviève Lajoie for

508 providing comments to an earlier version of this manuscript. We also would like to thank MaryAnn Pavlik, Anne Godbout, Jim Fyles from the Morgan Arboretum, for their help at the Arboretum

510 and permission to use the site.

511

\section{REFERENCES}

513

514

515

516

517

518

519

520

521

522

523

524

525

526

527

528

529

530

531

532

533

534
Aleklett K, Leff JW, Fierer N, Hart M. 2015. Wild plant species growing closely connected in a subalpine meadow host distinct root-associated bacterial communities. PeerJ 3:e804. DOI: $10.7717 /$ peerj.804.

Anderson MJ. 2001. A new method for non-parametric multivariate analysis of variance. Austral Ecology 26:32-46. DOI: 10.1111/j.1442-9993.2001.01070.pp.x.

Bellard C, Cassey P, Blackburn TM. 2016. Alien species as a driver of recent extinctions. Biology Letters 12:24-27. DOI: 10.1098/rsb1.2015.0623.

Berg G, Rybakova D, Grube M, Köberl M. 2016. The plant microbiome explored: Implications for experimental botany. Journal of Experimental Botany 67:995-1002. DOI: $10.1093 / \mathrm{jxb} / \mathrm{erv} 466$.

Berg G, Smalla K. 2009. Plant species and soil type cooperatively shape the structure and function of microbial communities in the rhizosphere. FEMS Microbiology Ecology 68:113. DOI: 10.1111/j.1574-6941.2009.00654.x.

Bever JD. 2003. Soil community feedback and the coexistence of competitors: Conceptual frameworks and empirical tests. New Phytologist 157:465-473. DOI: 10.1046/j.14698137.2003.00714.x.

Brundrett MC, Piché Y, Peterson RL. 1984. A new method for observing the morphology of vesicular-arbuscular mycorrhizae. Botany 62:2128-2134. DOI: 10.1139/b84-290.

Bunn RA, Lekberg Y, Gallagher C, Rosendahl S, Ramsey PW. 2014. Grassland invaders and their mycorrhizal symbionts: A study across climate and invasion gradients. Ecology and Evolution 4:794-805. DOI: 10.1002/ece3.917.

Peer] reviewing PDF | (2019:02:34915:2:0:NEW 27 May 2019) 
535 Bunn RA, Ramsey PW, Lekberg Y. 2015. Do native and invasive plants differ in their

536

537

538

539

540

541

542

543

544

545

546

547

548

549

550

551

552

553

554

555

556

557

558

559

560

561

562

563

564

565

566

567

568

569 interactions with arbuscular mycorrhizal fungi? A meta-analysis. Journal of Ecology 103:1547-1556. DOI: 10.1111/1365-2745.12456.

Callaway RM, Thelen GC, Rodriguez A, Holben WE. 2004. Soil biota and exotic plant invasion. Nature 427:731-733. DOI: 10.1038/nature02322.

Caporaso JG, Kuczynski J, Stombaugh J, Bittinger K, Bushman FD, Costello EK, Fierer N, Peña AG, Goodrich JK, Gordon JI, Huttley GA, Kelley ST, Knights D, Koenig JE, Ley RE, Lozupone CA, Mcdonald D, Muegge BD, Pirrung M, Reeder J, Sevinsky JR, Turnbaugh PJ, Walters WA, Widmann J, Yatsunenko T, Zaneveld J, Knight R. 2010. QIIME allows analysis of high- throughput community sequencing data Intensity normalization improves color calling in SOLiD sequencing. Nature Methods 7:335-336. DOI: 10.1038/nmeth0510335 .

Chelius MK, Triplett EW. 2001. The diversity of archaea and bacteria in association with the roots of Zea mays L. Microbial Ecology 41:252-263. DOI: 10.1007/s002480000087.

Cooke MA, Widden P, Halloran IO. 1992. Morphology, Incidence and Fertilization Effects on the Vesicular-Arbuscular Mycorrhizae of Acer saccharum in a Quebec Hardwood Forest. Mycologia 84:422-430.

Davison J, Moora M, Öpik M, Adholeya A, Ainsaar L, Bâ A, Burla S, Diedhiou AG, Hiiesalu I, Jairus T, Johnson NC, Kane A, Koorem K, Kochar M, Ndiaye C, Pärtel M, Reier, Saks, Singh R, Vasar M, Zobel M. 2015. Global assessment of arbuscular mycorrhizal fungus diversity reveals very low endemism. Science 349:970-973. DOI: 10.1126/science.aab1161.

DeSantis TZ, Hugenholtz P, Larsen N, Rojas M, Brodie EL, Keller K, Huber T, Dalevi D, Hu P, Andersen GL. 2006. Greengenes, a chimera-checked 16S rRNA gene database and workbench compatible with ARB. Applied and Environmental Microbiology 72:5069-5072. DOI: 10.1128/AEM.03006-05.

Dickie IA, Bufford JL, Cobb RC, Desprez-Loustau ML, Grelet G, Hulme PE, Klironomos J, Makiola A, Nuñez MA, Pringle A, Thrall PH, Tourtellot SG, Waller L, Williams NM. 2017. The emerging science of linked plant-fungal invasions. New Phytologist 215:1314-1332. DOI: $10.1111 / \mathrm{nph} .14657$.

Dumbrell AJ, Ashton PD, Aziz N, Feng G, Nelson M, Dytham C, Fitter AH, Helgason T. 2011. Distinct seasonal assemblages of arbuscular mycorrhizal fungi revealed by massively parallel pyrosequencing. New Phytologist 190:794-804. DOI: 10.1111/j.14698137.2010.03636.x.

Ehrenfeld JG. 2010. Ecosystem Consequences of Biological Invasions. Annual Review of Ecology, Evolution, and Systematics 41:59-80. DOI: 10.1146/annurev-ecolsys-102209- 
571 Elton C. 1958. Ecology of Invasions by Animals and Plants. US: Springer.

572 Galbraith-Kent SL, Handel SN. 2008. Invasive Acer platanoides inhibits native sapling growth in forest understorey communities Shannon. Journal of Ecology 96:293-302. DOI: 10.1111/j.1365-2745.2007.0.

Gardes M, Bruns TD. 1993. ITS primers with enhanced specificity for basiodiomycetes.pdf.

577

578

579

580

581

582

583

584

585

586

587

588

589

590

591

592

593

594

595

596

597

598

599

600

601

602 Molecular Ecology 2:113-118.

Gilbert GS, Webb CO. 2007. Phylogenetic signal in plant pathogen-host range. Proceedings of the National Academy of Sciences 104:4979-4983. DOI: 10.1073/pnas.0607968104.

Haichar FEZ, Marol C, Berge O, Rangel-Castro JI, Prosser JI, Balesdent J, Heulin T, Achouak W. 2008. Plant host habitat and root exudates shape soil bacterial community structure. ISME Journal 2:1221-1230. DOI: 10.1038/ismej.2008.80.

Harrison TL, Simonsen AK, Stinchcombe JR, Frederickson ME. 2018. More partners, more ranges: Generalist legumes spread more easily around the globe. Biology Letters 14. DOI: 10.1098/rsbl.2018.0616.

van der Heijden MGA, Horton TR. 2009. Socialism in soil? the importance of mycorrhizal fungal networks for facilitation in natural ecosystems. Journal of Ecology 97:1139-1150. DOI: $10.1111 / \mathrm{j} .1365-2745.2009 .01570 . x$.

Inderjit, van der Putten WH. 2010. Impacts of soil microbial communities on exotic plant invasions. Trends in Ecology and Evolution 25:512-519. DOI: 10.1016/j.tree.2010.06.006.

Johansen RB, Johnston P, Mieczkowski P, Perry GLW, Robeson MS, Burns BR, Vilgalys R. 2016. A native and an invasive dune grass share similar, patchily distributed, rootassociated fungal communities. Fungal Ecology 23:141-155. DOI: 10.1016/j.funeco.2016.08.003.

Jumpponen A. 2001. Dark septate endophytes - Are they mycorrhizal? Mycorrhiza 11:207-211. DOI: $10.1007 / \mathrm{s} 005720100112$.

Jumpponen A, Trappe JM. 1998. Dark septate endophytes: A review of facultative biotrophic root-colonizing fungi. New Phytologist 140:295-310. DOI: 10.1046/j.14698137.1998.00265.x.

Keane RM, Crawley MJ. 2002. Exotic plant invasions and the enemy release hypothesis. Trends Ecol. Evol. 17:164-170. DOI: 10.1016/S0169-5347(02)02499-0.

Kembel SW, Cowan PD, Helmus MR, Cornwell WK, Morlon H, Ackerly DD, Blomberg SP, Webb CO. 2010. Picante: R tools for integrating phylogenies and ecology. Bioinformatics 
603

604

605

606

607

608

609

610

611

612

613

614

615

616

617

618

619

620

621

622

623

624

625

626

627

628

629

630

631

632

633

634

635

636

26:1463-1464. DOI: 10.1093/bioinformatics/btq166.

Klironomos JNN. 1995. Arbuscular Mycorrhizae of Acer saccharum in Different Soil Types. Canadian Journal of Botany 73:1824-1830.

Klironomos JN. 2003. Variation in Plant Response to Native and Exotic Arbuscular Mycorrhizal Fungi. Ecology 84:2292-2301. DOI: 10.1890/02-0413.

Kloeppel BD, Abrams MD. 1995. Ecophysiological Attributes of the Native Acer saccharum and the Exotic Acer platanoides in Urban Oak Forests in Pennsylvania, Usa. Tree Physiology 15:739-746.

Knapp DG, Pintye A, Kovács GM. 2012. The dark side is not fastidious - dark septate endophytic fungi of native and invasive plants of semiarid sandy areas. PLOS ONE 7:1-8. DOI: 10.1371/journal.pone.0032570.

Kõljalg U, Larsson KH, Abarenkov K, Nilsson RH, Alexander IJ, Eberhardt U, Erland S, Høiland K, Kjøller R, Larsson E, Pennanen T, Sen R, Taylor AFS, Tedersoo L, Vrålstad T, Ursing BM. 2005. UNITE: A database providing web-based methods for the molecular identification of ectomycorrhizal fungi. New Phytologist 166:1063-1068. DOI: 10.1111/j.1469-8137.2005.01376.x.

Laforest-Lapointe I, Messier C, Kembel SW. 2016. Host species identity, site and time drive temperate tree phyllosphere bacterial community structure. Microbiome 4:1-10. DOI: 10.1186/s40168-016-0174-1.

Lankau R a. 2011. Resistance and recovery of soil microbial communities in the face of Alliaria petiolata invasions. New Phytologist 189:536-548. DOI: 10.1111/j.14698137.2010.03481.x.

Lee J, Lee S, Young JPW. 2008. Improved PCR primers for the detection and identification of arbuscular mycorrhizal fungi. FEMS Microbiology Ecology 65:339-349. DOI: 10.1111/j.1574-6941.2008.00531.x.

Leff JW, Bardgett RD, Wilkinson A, Jackson BG, Pritchard WJ, De Long JR, Oakley S, Mason KE, Ostle NJ, Johnson D, Baggs EM, Fierer N. 2018. Predicting the structure of soil communities from plant community taxonomy, phylogeny, and traits. ISME Journal 12:1794-1805. DOI: 10.1038/s41396-018-0089-x.

Linde S Van Der, Suz LM, Orme CDL, Cox F, Andreae H, Asi E, Atkinson B, Benham S, Carroll C, Cools N, Vos B De, Dietrich H, Eichhorn J, Titeux H, Vanguelova E, Verstraeten A, Vesterdal L, Waldner P, Wijk S, Zhang Y. 2018. Environment and host as large-scale controls of ectomycorrhizal fungi. DOI: 10.1038/s41586-018-0189-9.

Lockwood JF, Hoopes MF, Marchetti MP. 2006. Invasion Ecology. Wiley-Blackwell. 
637 Mandal S, Van Treuren W, White RA, Eggesbø M, Knight R, Peddada SD. 2015. Analysis of 638 composition of microbiomes: a novel method for studying microbial composition.

639 Microbial Ecology in Health \& Disease 26:1-7. DOI: 10.3402/mehd.v26.27663.

640 Mandyam KG, Jumpponen A. 2015. Mutualism-parasitism paradigm synthesized from results of 641 root-endophyte models. Frontiers in Microbiology 5:1-13. DOI:

$642 \quad 10.3389 /$ fmicb.2014.00776.

643 Marler MJ, Zabinski CA, Wojtowicz T, Callaway RM. 1999. Mycorrhizae and fine root 644 dynamics of Centaurea maculosa and native bunchgrasses in western Montana. Northwest $645 \quad$ Science 73:217-224.

646

647

648

649

650

651

652

653

654

655

656

657

658

659

660

661

662

663

664

665

666

667

668

669

670

Martin PH. 1999. Norway maple (Acer platanoides) invasion of a natural forest stand: understory consequence and regeneration pattern. Biological Invasions 1:215-222. DOI: 10.1023/A:1010084421858.

Mayerhofer MS, Kernaghan G, Harper KA. 2013. The effects of fungal root endophytes on plant growth: A meta-analysis. Mycorrhiza 23:119-128. DOI: 10.1007/s00572-012-0456-9.

McGonigle TP, Miller MH, Evans DG, Fairchild GL, Swan JA. 1990. A New Method which Gives an Objective Measure of Colonization of Roots by Vesicular- Arbuscular Mycorrhizal Fungi. New Phytologist 115:495-501. DOI: 10.1111/j.14698137.1990.tb00476.x.

Meiners SJ. 2005. Seed and Seedling Ecology of Acer saccharum and Acer platanoides: A Contrast Between Native and Exotic Congeners. Northeastern Naturalist 12:23-32. DOI: 10.1656/1092-6194(2005)012[0023:SASEOA]2.0.CO;2.

Moora M, Berger S, Davison J, Öpik M, Bommarco R, Bruelheide H, Kühn I, Kunin WE, Metsis M, Rortais A, Vanatoa A, Vanatoa E, Stout JC, Truusa M, Westphal C, Zobel M, Walther GR. 2011. Alien plants associate with widespread generalist arbuscular mycorrhizal fungal taxa: Evidence from a continental-scale study using massively parallel 454 sequencing. Journal of Biogeography 38:1305-1317. DOI: 10.1111/j.1365-2699.2011.02478.x.

Newsham KK. 2011. A meta-analysis of plant responses to dark septate root endophytes. New Phytologist 190:783-793. DOI: 10.1111/j.1469-8137.2010.03611.x.

Nguyen NH, Song Z, Bates ST, Branco S, Tedersoo L, Menke J, Schilling JS, Kennedy PG. 2016. FUNGuild: An open annotation tool for parsing fungal community datasets by ecological guild. Fungal Ecology 20:241-248. DOI: 10.1016/j.funeco.2015.06.006.

Nowak D, Rowntree R. 1990. History and range of norway maple. Journal of Arboriculture 16:291-296. DOI: citeulike-article-id:13501537.

Nuñez MA, Dickie IA. 2014. Invasive belowground mutualists of woody plants. Biological 
672 Oksanen J, Blanchet FG, Friendly M, Kindt R, Legendre P, McGlinn D, Minchin PR, O'Hara

673 RB, Simpson GL, Solymos P, Stevens MHH, Szoecs E, Wagner H. 2017. vegan:

674 Community Ecology Package.

675 Öpik M, Metsis M, Daniell TJ, Zobel M, Moora M. 2009. Large-scale parallel 454 sequencing 676 reveals host ecological group specificity of arbuscular mycorrhizal fungi in a boreonemoral 677 forest. New Phytologist 184:424-437. DOI: 10.1111/j.1469-8137.2009.02920.x.

678 Öpik M, Vanatoa A, Vanatoa E, Moora M, Davison J, Kalwij JM, Reier Ü, Zobel M. 2010. The 679 online database MaarjAM reveals global and ecosystemic distribution patterns in arbuscular 680 681 mycorrhizal fungi (Glomeromycota). New Phytologist 188:223-241. DOI: 10.1111/j.14698137.2010.03334.x.

Packer A, Clay K. 2000. Soil pathogens and spatial patterns of seedling mortality in a temperate tree. Nature 404:278-281. DOI: 10.1038/35005072.

Paquette A, Fontaine B, Berninger F, Dubois K, Lechowicz MJ, Messier C, Posada JM,

685 Valladares F, Brisson J. 2012. Norway maple displays greater seasonal growth and phenotypic plasticity to light than native sugar maple. Tree Physiology 32:1339-1347. DOI: 10.1093/treephys/tps092.

Porras-Alfaro A, Raghavan S, Garcia M, Sinsabaugh RL, Natvig DO, Lowrey TK. 2014. Endophytic fungal symbionts associated with gypsophilous plants. Botany 92:295-301. DOI: $10.1139 / \mathrm{cjb}-2013-0178$.

Pringle A, Bever JD, Gardes M, Parrent JL, Rillig MC, Klironomos JN. 2009. Mycorrhizal Symbioses and Plant Invasions. Annual Review of Ecology, Evolution, and Systematics

694 R Development Core Team. 2013. A Language and Environment for Statistical Computing.

Redford AJ, Bowers RM, Knight R, Linhart Y, Fierer N. 2010. The ecology of the phyllosphere: Geographic and phylogenetic variability in the distribution of bacteria on tree leaves. Environmental Microbiology 12:2885-2893. DOI: 10.1111/j.1462-2920.2010.02258.x.

Reinhart KO, Anacker BL. 2014. More closely related plants have more distinct mycorrhizal communities. AoB PLANTS 6:1-10. DOI: 10.1093/aobpla/plu051.

Reinhart KO, Callaway RM. 2006. Soil biota and invasive plants. The New Phytologist 170:445457. DOI: 10.1111/j.1469-8137.2006.01715.x.

702

Reinhart KO, Callaway RM. 2004. Soil biota facilitate exotic Acer invasions in Europe and North America. Ecological Applications 14(6):1737-1745. DOI: 10.1890/03-5204. 
704 Reinhart KO, Greene E, Callaway RM. 2005. Effects of Acer platanoides invasion on understory

705

706

707

708

709

710

711

712

713

714

715

716

717

718

719

720

721

722

723

724

725

726

727

728

729

730

731

732

733

734

735

736

737 plant communities and tree regeneration in the northern Rocky Mountains. Ecography 28:573-582. DOI: $10.1111 / j .2005 .0906-7590.04166 . x$.

Reinhart KO, Packer A, Van Der Putten WH, Clay K. 2003. Plant-soil biota interactions and spatial distribution of black cherry in its native and invasive ranges. Ecology Letters 6:1046-1050. DOI: 10.1046/j.1461-0248.2003.00539.x.

Reinhart KO, Tytgat TOG, Van der Putten WH, Clay K. 2010. Virulence of soil-borne pathogens and invasions by Prunus serotina. New Phytologist 186:484-495. DOI: 10.1111/j.14698137.2009.03159.x.

Richardson DM, Rejmánek M. 2011. Trees and shrubs as invasive alien species - a global review. Diversity and Distributions 17:788-809. DOI: 10.1111/j.1472-4642.2011.00782.x.

Rodriguez R, Redman R. 2008. More than 400 million years of evolution and some plants still can't make it on their own: Plant stress tolerance via fungal symbiosis. Journal of Experimental Botany 59:1109-1114. DOI: 10.1093/jxb/erm342.

Smith S., Read D. 2008. Mycorrhizal Symbiosis. London: Academic Press.

Tellenbach C, Grünig CR, Sieber TN. 2011. Negative effects on survival and performance of Norway spruce seedlings colonized by dark septate root endophytes are primarily isolatedependent. Environmental Microbiology 13:2508-2517. DOI: 10.1111/j.14622920.2011.02523.x.

Thomas CD, Palmer G. 2015. Non-native plants add to the British flora without negative consequences for native diversity. Proceedings of the National Academy of Sciences 112:4387-4392. DOI: 10.1073/pnas.1423995112.

Toole DR, Cannon GH, Brislawn CJ, Graves JM, Lamendella R, Muth TR, Muth NZ. 2018. Differences in soil fungal assemblages associated with native and non-native tree species of varying weediness. Biological Invasions 20:891-904. DOI: 10.1007/s10530-017-1580-4.

Uroz S, Oger P, Tisserand E, Cébron A, Turpault MP, Bueé M, De Boer W, Leveau JHJ, FreyKlett P. 2016. Specific impacts of beech and Norway spruce on the structure and diversity of the rhizosphere and soil microbial communities. Scientific Reports 6:1-11. DOI: $10.1038 /$ srep27756.

Vandenkoornhuyse P, Quaiser A, Duhamel M, Le Van A, Dufresne A. 2015. The importance of the microbiome of the plant holobiont. New Phytologist 206:1196-1206. DOI: 10.1111/nph.13312.

Veresoglou SD, Rillig MC. 2014. Do closely related plants host similar arbuscular mycorrhizal fungal communities? A meta-analysis. Plant and Soil 377:395-406. DOI: 10.1007/s11104- 
738

739

740

741

742

743

744

745

746

747

748

749

750

751

752

753

754

755

756

757

758

759

760

761

762

763

764

765

766

767

768

769

770

771

013-2008-2.

Vilà M, Espinar JL, Hejda M, Hulme PE, Jarošík V, Maron JL, Pergl J, Schaffner U, Sun Y, Pyšek P. 2011. Ecological impacts of invasive alien plants: A meta-analysis of their effects on species, communities and ecosystems. Ecology Letters 14:702-708. DOI: 10.1111/j.1461-0248.2011.01628.x.

Wallace J, Laforest-Lapointe I, Kembel SW. 2018. Variation in the leaf and root microbiome of sugar maple (Acer saccharum) at an elevational range limit. PeerJ 6:e5293. DOI: 10.1103/PhysRevB.74.094517.

Webb SL, Dwyer M, Kaunzinger CK, Wyckoff PH. 2000. The myth of the resilient forest: Case study of the invasive Norway maple (Acer platanoides). Rhodora 102:332-354.

Van Wees SC, Van der Ent S, Pieterse CM. 2008. Plant immune responses triggered by beneficial microbes. Current Opinion in Plant Biology 11:443-448. DOI: 10.1016/j.pbi.2008.05.005.

Wehner J, Powell JR, Muller LAH, Caruso T, Veresoglou SD, Hempel S, Rillig MC. 2014. Determinants of root-associated fungal communities within Asteraceae in a semi-arid grassland. Journal of Ecology 102:425-436. DOI: 10.1111/1365-2745.12197.

Weiss S, Xu ZZ, Peddada S, Amir A, Bittinger K, Gonzalez A, Lozupone C, Zaneveld JR, Vázquez-Baeza Y, Birmingham A, Hyde ER, Knight R. 2017. Normalization and microbial differential abundance strategies depend upon data characteristics. Microbiome 5:1-18. DOI: 10.1186/s40168-017-0237-y.

White TJ, Bruns T, Lee S, Taylor J. 1990. Amplification and direct sequencing of fungal ribosomal RNA genes for phylogenetics. In PCR protocols: a guide to methods and applications. In: PCR protocols: a guide to methods and applications. New York: Academic Press, 315-322.

Wickham H. 2009. ggplot2: elegant graphics for data analysis. New York: Springer.

Widden P. 2001. The use of glycerine jelly for mounting stained roots for the observation and quantification of VAM fungi. Mycologia 93:1026-1027.

Wilcox WE, Wang CJK. 1987. ECM and ECM associations of Phialophora finlandia with Pibus resinosa, Picea rubens, and Betual alleghaniensis. Canadian Journal of Forest Research 17:976-990.

Wolfe BE, Klironomos JN. 2005. Breaking new ground: Soil communities and exotic plant invasion. Bioscience 55:477-487. DOI: 10.1641/00063568(2005)055[0477:bngsca]2.0.co;2.

Wyckoff PH, Webb SL. 1996. Understory influence of the invasive Norway maple (Acer 
772 platanoides). Bulletin of the Torrey Botanical Club 123:197-205. DOI: 10.2307/2996795.

773 Zhang J, Kobert K, Flouri T, Stamatakis A. 2014. PEAR: A fast and accurate Illumina Paired774 End reAd mergeR. Bioinformatics 30:614-620. DOI: 10.1093/bioinformatics/btt593.

775

776 


\section{Table 1 (on next page)}

Microbial community structure variation among maple roots explained by various factors (PERMANOVA on Bray-Curtis dissimilarities). P-values are based on 999 permutations. 
1 Table 1. Microbial community structure variation among maple roots explained by various

2 factors (PERMANOVA on Bray-Curtis dissimilarities). P-values are based on 999 permutations.

3

\begin{tabular}{llcc}
\hline \multirow{2}{*}{$\begin{array}{l}\text { Microbial } \\
\text { Community }\end{array}$} & Variable & \multicolumn{2}{c}{ Bray-Curtis dissimilarities } \\
\cline { 3 - 4 } Bacteria & & $\mathrm{R}^{2}(\%)$ & $\operatorname{Pr}(>\mathrm{F})$ \\
& Species & 3.6 & .001 \\
& Date & 1.6 & .003 \\
Species*Date & & .204 \\
Fungi & Species & 8.4 & .001 \\
& Date & 1.8 & .084 \\
& Species*Date & 1.2 & .519 \\
AMF & & & \\
& Species & 1.5 & .349 \\
& Date & 0.6 & .979 \\
& Species*Date & 1.2 & .576 \\
\hline
\end{tabular}

4

7 
Figure 1

Relative abundance (\%) of the main taxa detected among the microbial communities in the roots of Norway and sugar maple.

(a) Bacterial communities (Order); (b) Fungi ITS (Order); (c) AMF (Family level). The stacked bar graphs represent the overall relative abundance across the entire dataset. 
a

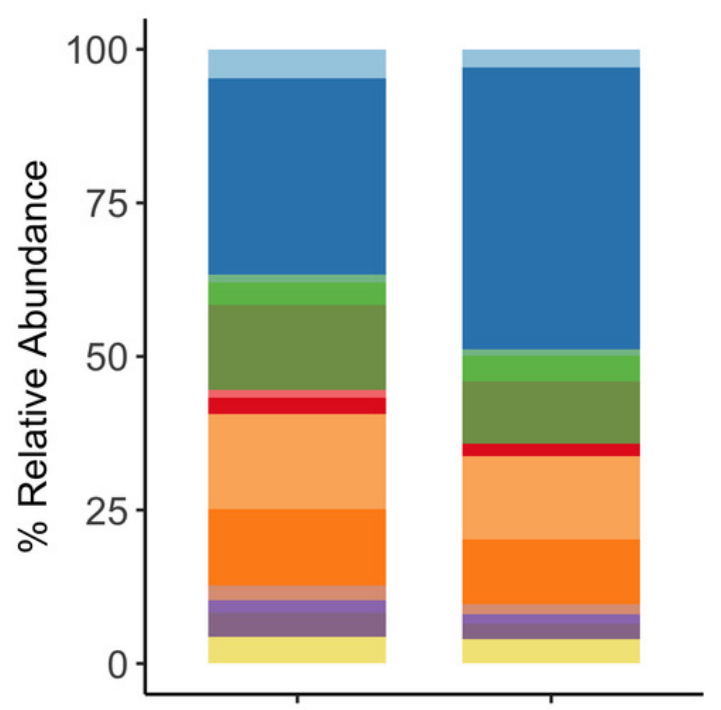

b

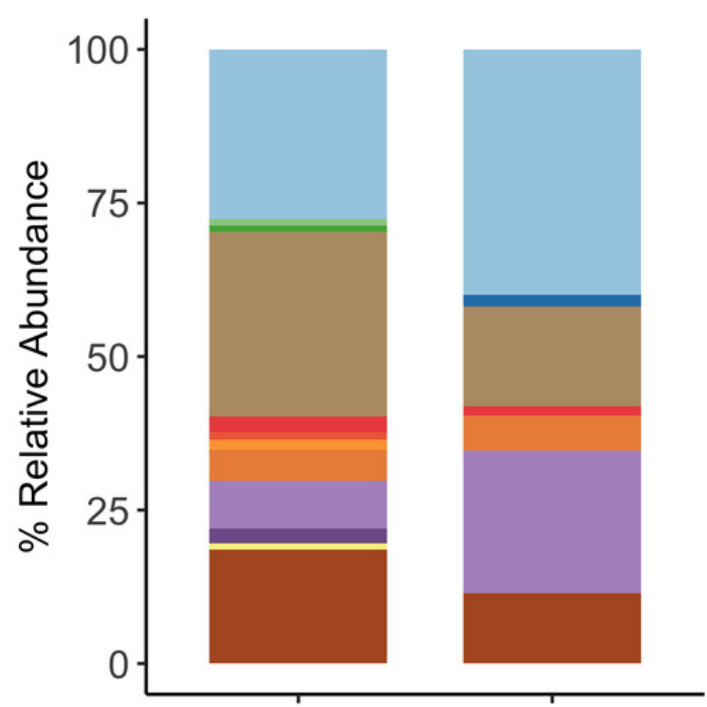

C

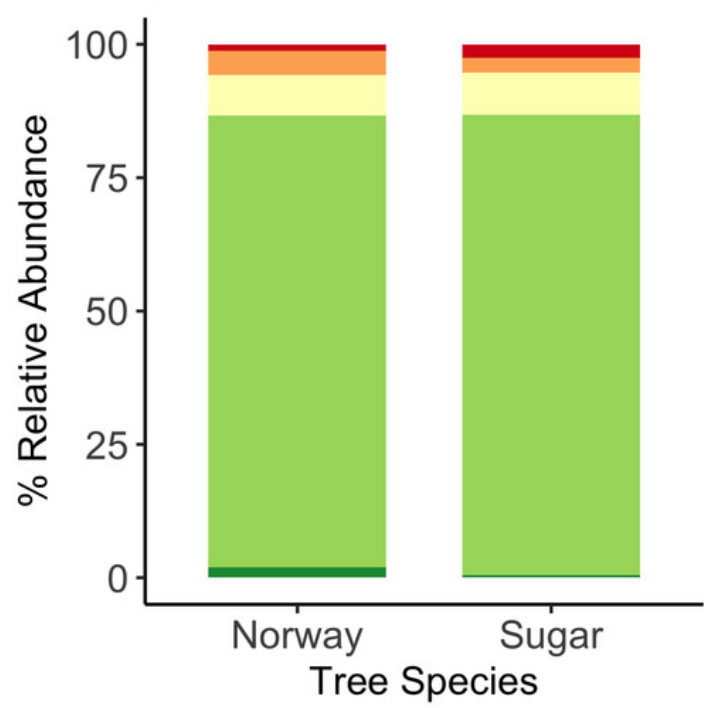

Order

Acidimicrobiales

Actinomycetales

Bacillales

Burkholderiales

Gaiellales

Methylophilales

Myxococcales

Other

Rhizobiales

Rhodospirillales

Saprospirales

Solirubrobacterales

Xanthomonadales

\section{Order}

Agaricales

Capnodiales

Chaetothyriales

Diversisporales

Helotiales

Hypocreales

Incertae

Mortierellales

Other

Pleosporales

Trechisporales

Tremellales

unidentified
Family

Acaulosporaceae

Claroideoglomeraceae

Diversisporaceae

Glomeraceae

Other 


\section{Figure 2}

Plots of (a) Bacterial, (b) Fungal, and (c) AMF communities associated with the roots of sugar and Norway maples based on 18S, ITS and 16S regions (respectively) using NMDS scaling.

Ordinations based on Bray-Curtis distances among samples. Ellipses indicate 2 standard deviations around samples from each host species. Stress values for bacterial, fungal and AMF ordinations are 0.17 in 2D space, 0.17 and 0.19 in 3D space, respectively. 

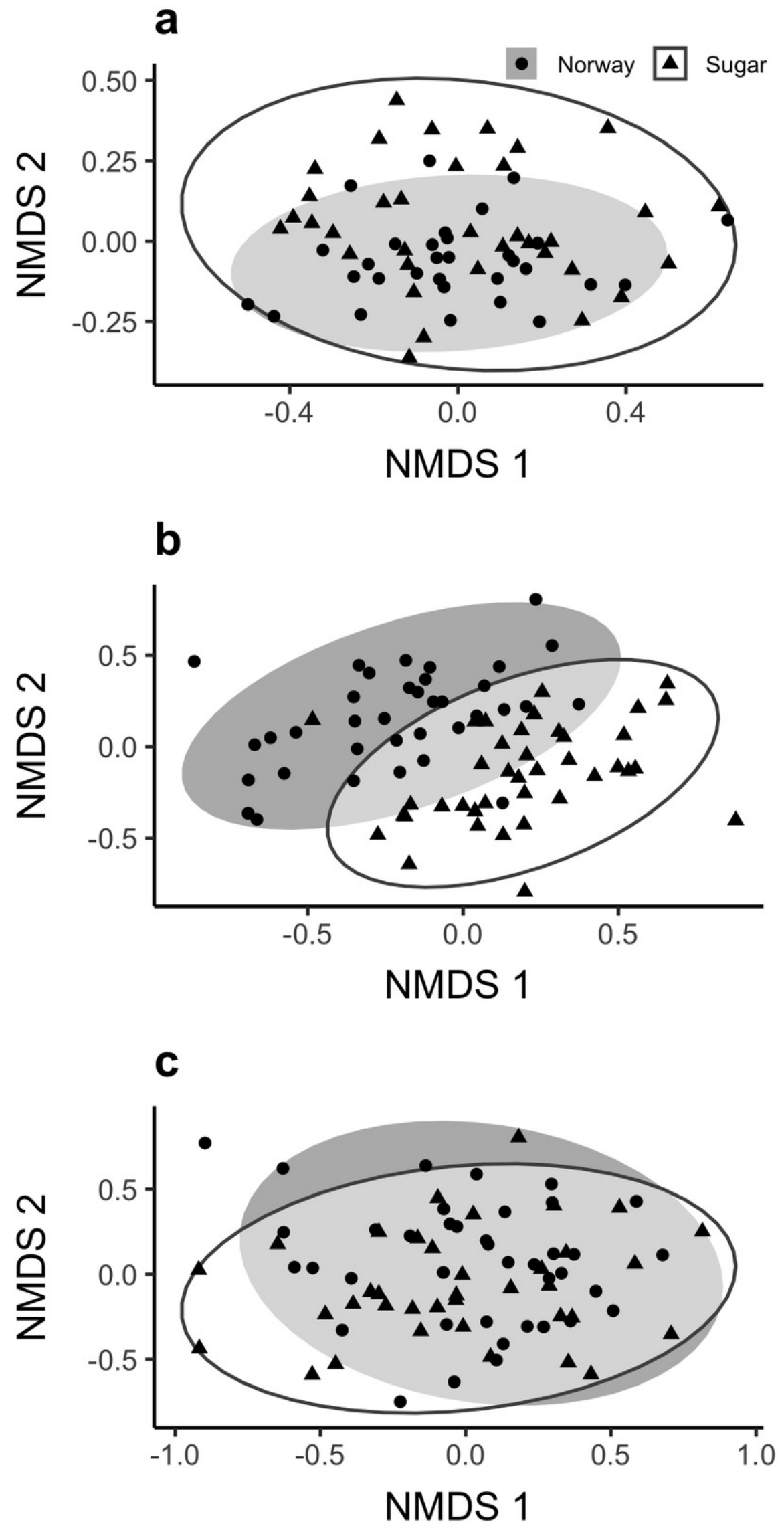
Figure 3

Boxplots of median bacterial (a) and fungal (b) taxa that differed significantly in abundance among maple species (ANCOM, $P<0.05$ ). Whiskers represent interquartile range (IQR) x 1.5. 

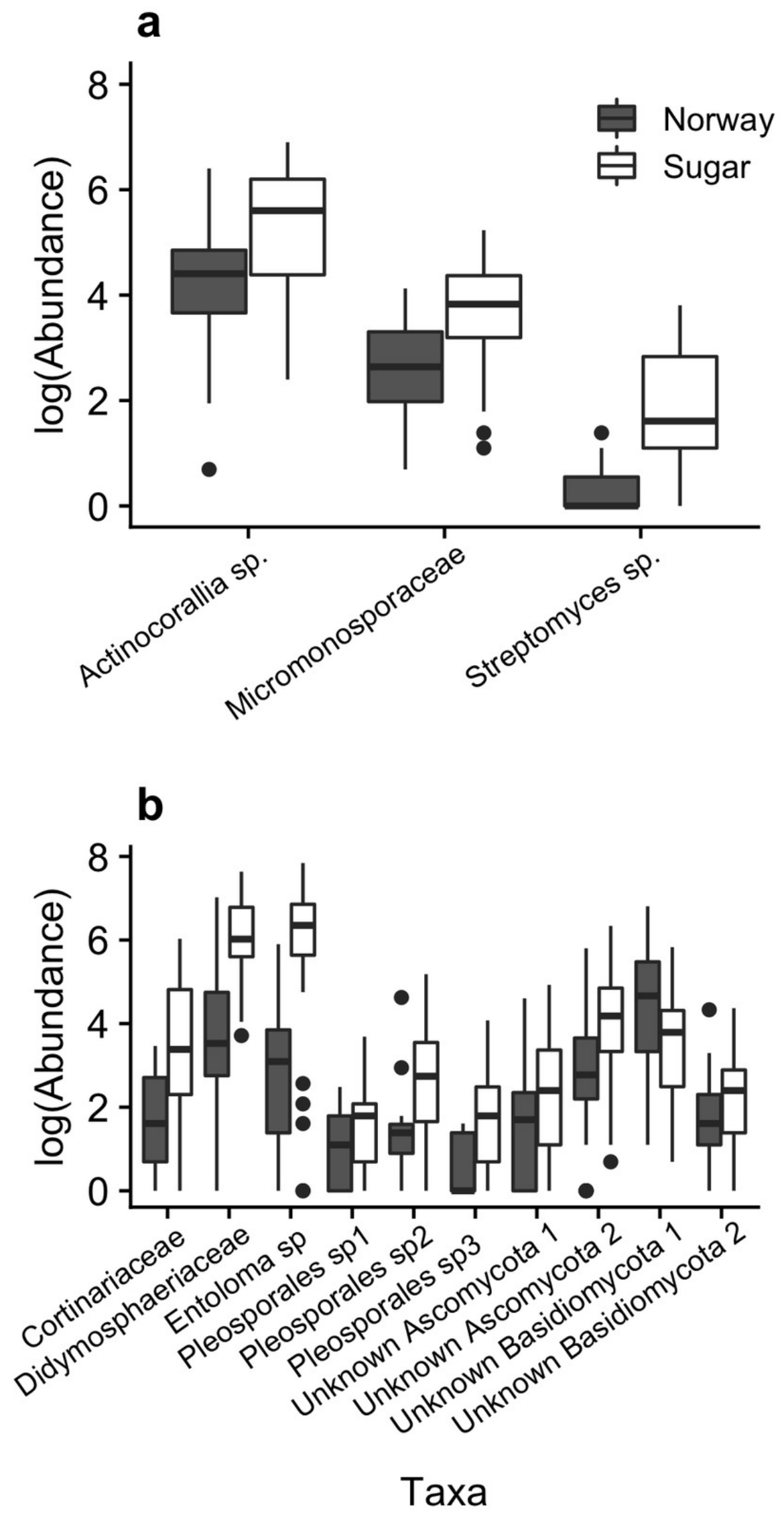


\section{Figure 4}

Percent root colonization of mycorrhizal and dark septate endophytes in the Norway maple (Norway) and sugar maple (Sugar) throughout the sampling period (mean $\pm \mathrm{SE}$ ).

(a) Vesicular colonization, percent of root length containing mycorrhizal vesicles; (b) Arbuscular colonization, percent of root length containing arbuscules; (c) Dark septate endophyte colonization, percent of root length containing dark septate fungi. Symbols above bars indicate a significance difference $(P<0.05)$ between species at the specified sampling date based on the two-way ANOVA and Tukey post-hoc test. 

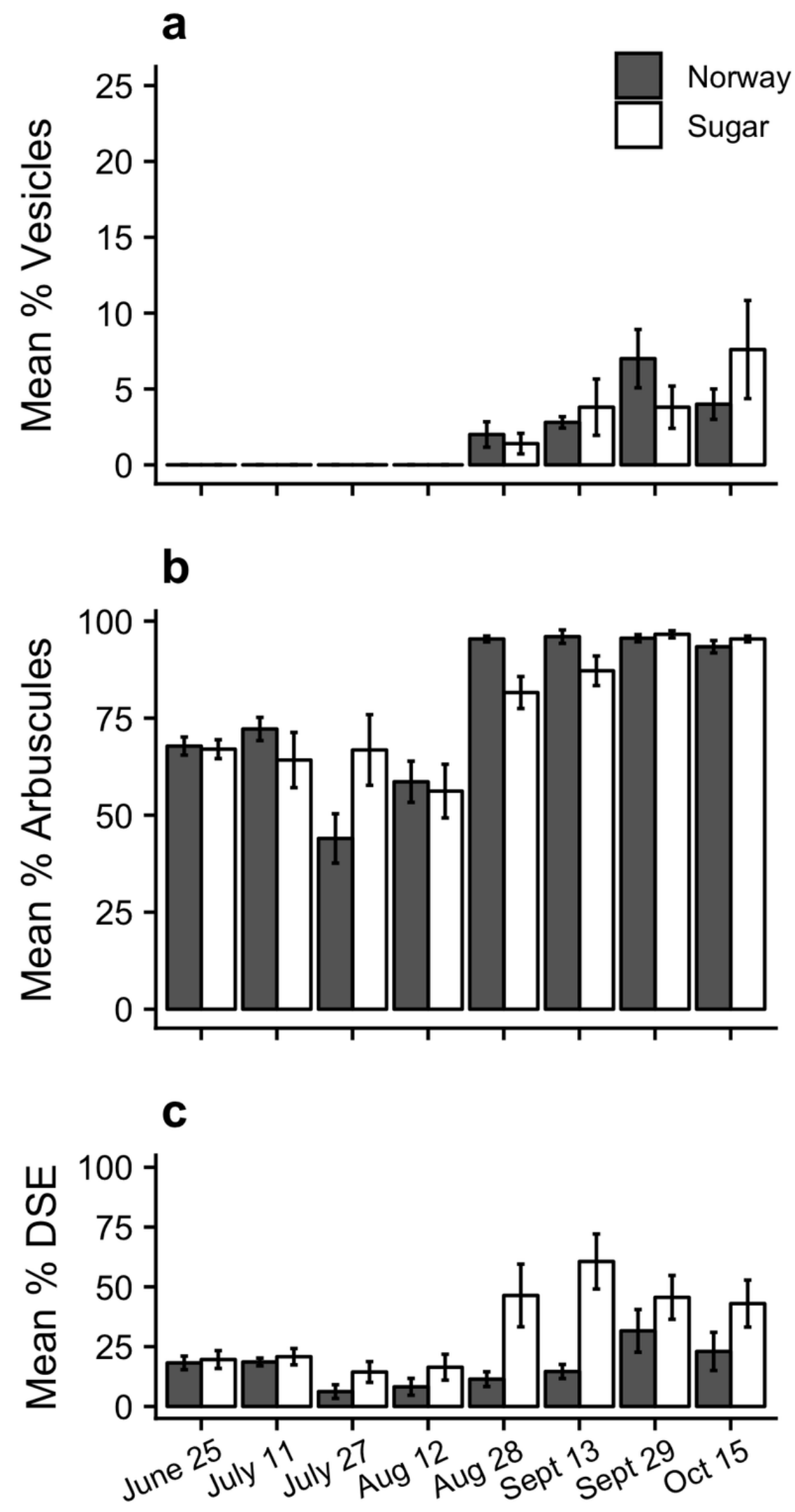

Sampling Date 